Mart Raukas

\title{
THE ROLE OF PERFECTIONS IN INTER-RELIGIOUS DISCOURSE
}

This is a copy of the article from printed version of electronic journal

\section{Folklore Vol. 15}

ISSN 1406-0957

Editors Mare Kõiva \& Andres Kuperjanov

Published by the Folk Belief and Media Group of ELM

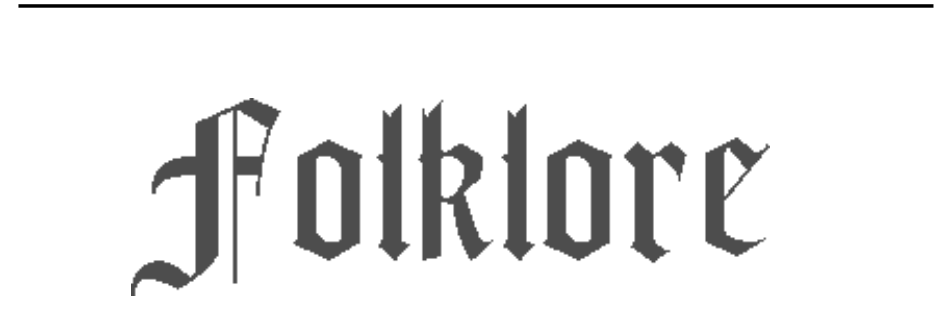

\section{Electronic Journal of Folklore}

Electronic version ISSN 1406-0949 is available from http://haldjas.folklore.eelfolklore

It's free but do give us credit when you cite!

(C) Folk Belief and Media Group of ELM, Andres Kuperjanov

\section{Tartu 2000}




\section{THE ROLE OF PERFECTIONS IN INTER- RELIGIOUS DISCOURSE}

\section{Mart Raukas}

\section{INTRODUCTORY REMARKS}

This paper is not a discussion of the concept of perfection but discusses the concept of perfection in inter-religious discourse.

The way we present arguments depends on the kind of references we are using. In religious discourse we often do not present arguments and draw conclusions from the concept of God, but from singular perfections such as 'ultimate goodness', 'absolute love', 'superior wisdom', etc. These denote, under certain conditions, God although "God" does not have the same meaning as "ultimate goodness".

This form of discourse has become normal in inter-religious debates, where a rigid concept of God (whatever is meant by this) is often replaced by more flexible referential descriptions. Some philosophical theologians, too, see good reason for the flexible talk about God:

Conceptual frameworks come and go. This does not mean that we should not try to understand the very meaning of the God of Israel and the God of Jesus, but that we have to look for another conceptuality, one that will take into account all that we know about the world in which we live. (Van der Vekken 1992: 163)

This strategy enables us to overcome cultural differences and construct inter-religious discourse in which the univocal use of "God" has been substituted by equivocal and analogous uses of the concepts of good, love and wisdom.

There are, however, problematic cases, if we suppose that some cultures or religious groups lack one or more concepts of perfection. Semantic investigations have established a provisional set of human concepts that are expressed by identifiable words in all lan- 
guages. This set includes nearly sixty elements, providing a transcultural framework for analysing meanings across languages and cultures in the form of trans-cultural metalanguage.

According to linguistical investigations, certain Papuan tribes lack the concept of love (Wierzbika 1995: 210). This fact, stated by linguists as an empirical one, creates a theoretical problem: Which forms of argumentative discourse are effective when speaking with Papuas about God as ultimate love? Can inter-religious argumentation be construed in trans-cultural metalanguage if there is no place for the concepts of divine perfections like 'love' or 'wisdom'?

\section{THE CONCEPT OF PERFECTIONS AND CONCEPTUAL FRAMEWORK}

Good arguments usually convince people. At least they convince those that understand how the argument works. It is also widely assumed any argument which uses commonly understandable and univocal concepts is more convincing than one using non-understandable and equivocal concepts. For instance, missionaries who work with natives know well that preaching in the name of 'ultimate love' is usually much more effective than the concepts of 'primal cause' or 'first mover'. For to provide effective arguments they need to rely on a conceptual framework suitable for the audience.

Now let us come to the question: What are the concepts common for all humanity? According to linguistic semantics, in particular to the Goddard and Wierzbicka's "NSM" school of semantics (Goddard \& Wierzbicka 1994) the answer is: the set of universal human concepts. The set of universal human concepts has been established on the basis of cross-linguistic investigations and contains several substantives (I, you, someone/person, something/thing, people, body), determines (this, the same, other), quantifiers (one, two, many, all, some), mental predicates (think, know, feel want, see, hear), etc. As to the attributes: "good", "bad", "big", "small" are universal, while for instance "love", "wisdom" are not universal concepts for the humanity. According to Wierzbicka, there are some tribes for whom arguments of "love" are non-understandable because they do not have a corresponding concept in their tribal language. How, then, could the missionary tell something about Jesus as Perfect Love? 
Not telling about this concept would badly harm the very understanding what Christian God is. In Biblical parables, love is a central and highly important topic. It is also true that the most effective inter-religious arguments will take their start from "love".

\section{WIERZBICKA'S PARABLE EXPLICATION PROJECT}

Prof. Wierzbicka's project offers a solution to the problem in the use of universal human concepts. For the Biblical parable of the Lost Sheep (Lost Son, Lost coin) in which the idea of love is central, she proposes following explanations in the set of universal human concepts:

God wants to do good things for all people

all people can line with God

God wants this

God does many things because of this

sometimes a person doesn't want to live with God

because this person wants to do bad things

this is bad for this person

if you don't want to live with God

because you want to do bad things

this is bad for you

God wants you to think something like this:

"I don't want to do bad things any more"

"I want to live with God"

God does many thing because of this...

(Wierzbicka 1997: 18)

Wierzbicka seems to think that her explanation of the Lost Sheep in terms of universal human concepts refers to God of Love principally in the same way the original parable does (Wierzbicka 1997: 18). She rejects the view that metaphorical expressions could not be paraphrased, and her project is aimed to provide Christian missionaries with many other universalised parables, which, however, turn out to be strikingly sketchy and similar to each other.

Let us next consider the quesion: Can good inter-religious arguments be construed by such highly artificial explanations of the parables? Could any better understanding of what God of Love re- 
ally mean be achieved by the tribesmen by using them? I personally doubt this. Moreover, Wierzbicka's idea of the set of universal human concepts seems strange to me. Practising missionaries will probably be able to tell more exactly why Wierzbika's concepts do not work in practice; I will limit my criticism to philosophical objections. In the following I aim to show why Wierzbicka's project could be called Frankensteinian, how despite the good intentions it fails to recognise the essential way humans are having their life. I will also provide an alternative approach for arguments from perfections.

\section{METHODOLOGICAL BACKGROUND}

Why is Wierzbicka so certain that the concept 'love' is not universal? That linguistical investigation has proved that certain cultures lack this concept simply means that a particular culture does not have a corresponding expression as an identifiable word in their vocabulary. But does this empirically stated fact mean that this culture lacks the very idea of love? And that in order to explain tribesmen what God means in therms of love, one has to use Wierzbicka's translations? Moreover, why should we recognise this strange tribe as humans and not human-like robots, or human-like lions? Just to think of the different forms love is manifested and manifests, and how these manifestations are related to humans' everyday life. The relations between a mother and her child, the feelings between a young man and woman; and the mixture of love and pain you feel when someone close to you suddenly dies? Should we suppose that nothing of the kind exists in some culture? Could anyone imagine that members of a culture experience the feelings we call 'love'? Or that they have feelings, thoughts and ideas, but are never conscious about them. If so, how do we know that we are dealing with a human culture?

What I mean is not that the tribesmen are not always kind or friendly, or that they never prefer wise acts to silly deeds. Certainly, there exist some cultures, where love is not part of everyday life. What I want to emphasise is that it is very odd to imagine the human race without it having the slightest idea what 'love' and 'wisdom' are. Because manifestations of love are universal for hu- 
mans, and because the way of life led by people who have no concept or manifestaion of 'love' would be very different from ours, we would be quite uncertain about how to interpret their social practices. Even if such a tribesman were addressing us using plain English expressions, we would not be able to decide whether he in fact has in mind the same meaning we normally attribute to these expressions. George Pitcher has commented on Wittgensteins' saying "If the lion could speak, we would not understand him":

Suppose a lion says: "It is now three o'clock" but without at a clock his wrist-watch-and we may imagine that it would be merely a stroke of luck if he should say this when it actually is three o'clock. Or suppose he says: "Goodness, it is three o'clock; I must hurry to make that appointment", but that he continues to lie there, yawing, making no effort to move, as lions are wont to do. In these circumstances - assuming that the lions general behaviour is in every respect exactly like that of an ordinary lion, save for his amazing ability to utter English sentences - we could not say that he has asserted or stated that it is three o'clock, even though he uttered suitable words. We could not tell what, if anything, he has asserted, for the modes of behaviour into which his use of words is woven are too radically different from our own. We could not understand him, since he does not share the relevant forms of life with us. (Pitcher 1965: 243)

In which sense then are the members of a culture without love more humans than talking lions or marionettes? If they do not posses the slightest idea that love is, could we not say that their life is too different from ours? (Raukas 1996: 39).

\section{AN AUGUSTINIAN MODEL}

Why not admit that a culture without the explicit words for it still has the concepts of, for example 'love' and 'wisdom'? It is more realistic to deduct that from whether these concepts are manifest in their everyday life and practices. But this is what Wierzbicka's investigation indirectly denies. Of course, she probably admits that the absent of a certain concepts in vocabulary does not make Papuas non-humans, but she denies (at least indirectly) their conceptual consciousness of love. 
Why are some linguists reluctant to embrace these conclusions? It seems they fear that if concepts and ideas are not equated with easily identifiable linguistical expressions discoverable by simple empirical methods then they lose every possibility to see how these concepts and ideas work in the human mind. The philosophical understanding of language-world connections of such linguists is the old-fashioned Augustinian idea. They tend to think, as Wittgenstein puts it in his Philosophical Investigations, that

the individual expression in language name objects - sentences are combinations of such names. - In this picture of language we find the roots of the following idea: Every word has a meaning. This meaning is correlated with the word. It is the object for which the word stands. (Wittgenstein 1953: 1)

Let us presume for a moment that there are also other concepts besides 'love' that a certain human culture does not have in its vocabulary. What about the ideas of 'nonsense' or 'criticism'? The linguist who follows her Augustinian empirical methods is probably telling us that this culture does not have the slightest idea what 'nonsense' and 'criticism' are just because this culture lacks easily identifiable words to denote them. Therefore, all attempts to present argumentats based on the concept of nonsense to this culture should be explicated via the set of universal human concepts, similar to Wierzbicka's Biblical parable explications.

But is this really the way out? If the way of life of the members of such a culture is similar to ours then we are admitting not only that they are human beings but also that in their behaviour they express desires, feelings and thoughts just as we do. Wierzbicka ignores the diverse ways in which the language of the tribe does enter the lives of people.

\section{AN ALTERNATIVE APPROACH TO THE PROBLEM}

In Philosophical Investigations Wittgenstein describes two men working with building stones. One of them shouts orders, the other reacts to the orders. Wittgenstein says this might be not only the language but the entire language of the tribe. 
To understand what Wittgenstein means by 'entire language' I present an example from Malcolm in his Language Game (Malcolm 1995: 179). This example should explicate my claim that 'love', 'nonsense' and 'criticism' can be seen in the language of any culture simply because they are humans and their behaviour is similar to ours, not because linguistical investigations have proved that there are (or are not) linguistical expressions in their vocabulary.

Let us suppose that a worker is building a wall. Only slabs are used in walls: beams are used only in roofs. We may even suppose that beams physically cannot be used in walls because of their shape. Now this builder, at work on a wall, calls out to his helper "Beam". The helper looks at him in astonishment - then bursts into laughter. The startled builder looks at the helper, then at the wall, then back at helper with grin of embarrassment. He slaps himself on the head, and then calls out "Slab". The chuckling helper brings him a slab. Cannot we say that the builder's original call, "Beam", was, in that situation, nonsense, and that first the helper and then the builder perceived that it was nonsense? (Malcolm1995: 179).

Likewise with love. It is true, that some languages lack the explicit word for love. However, only the blind and dumb cannot see and hear the way love is naturally manifested in their everyday life.

\section{CONCLUDING REMARKS}

I have discussed two different approaches to the inter-religious (or inter-cultural) discourse. First, I tackled prof. Wierzbika's highly optimistic project to translate Biblical parables into a trans-cultural language which contains only universal concepts. I claim that Wierzbika's inter-religious discourse lacks (beside its theological and philosophical point) argumentative force. Firstly, because her model interprets the empirical facts of linguistics by the too much simplified philosophical Augustinian theory of language and how words could have their meanings in language. Secondly, the phrasal equivalents to 'God', 'love' and 'wisdom' in the set of universal human concepts are greatly equivocal. 
An alternative approach takes its start from the Wittgensteinian idea that according to which speaking a language is participating in a social activity with elaborate rules. I maintain that referential practice does not necessarily require the use of universal concepts, but necessarily assumes certain common practices. If we have good reasons to presuppose that different cultures are not too far from ours - in the sense that in their natural behaviour they express their desires, feelings and thoughts just as we do - using in argumentations perfections such as 'love', does not necessarily imply equivocation, which would undermine our normal argumentative models.

I had originally intended to say more about Wittgensteinian-type arguments about perfections. However, in the process of writing the paper I changed my mind and merely called to your attention the way good arguments could not be stated.

Translated by the author.

\section{References}

Goddard, R \& Wierzbicka, A. (eds.) 1994. Semantic and Lexical Universales. Amsterdam: John Benjamins.

Malcolm, N. 1995. Wittgensteinian Themes. Ithaca \& London: Cornell University Press.

Pitcher, G. 1965. The Philosophy of Wittgenstein. London: Englewood Cliffs.

Raukas, M. 1996. St. Thomas Aquinas on the Speech of the Angels. Freiburger Zeitschrift für Philosophie und Theologie. Heft 1/2, pp. 30-44.

Van der Vekken, J. 1992. The referent of the word "God". Tradition and Renewal. D. A. Boileau \& J. A. Dick (eds.). Louvain: Leuven University Press, pp. 162-173.

Wierzbicka, A. 1995. Kisses, bows and handshakes. Semiotica, 103, 3/ 4 , pp. 207-252.

Wierzbicka, A. 1997. The Meaning of Jesus Parables. A Semantic Approach to the Gospels. Duisburg: L.A.U.D.

Wittgenstein, L. 1953. Philosophical Investigations. Oxford: Basil Blackwell. 